University of Nebraska - Lincoln

DigitalCommons@University of Nebraska - Lincoln

Faculty Publications: Department of Entomology

2001

\title{
Arthropod Populations and Rice Yields in Direct-Seeded and Transplanted Lowland Rice in West Africa
}

I. O. Oyediran

University of Nebraska-Lincoln

E. A. Heinrichs

University of Nebraska-Lincoln, eheinrichs2@unl.edu

Follow this and additional works at: https://digitalcommons.unl.edu/entomologyfacpub

Part of the Agriculture Commons, Agronomy and Crop Sciences Commons, and the Entomology

Commons

Oyediran, I. O. and Heinrichs, E. A., "Arthropod Populations and Rice Yields in Direct-Seeded and Transplanted Lowland Rice in West Africa" (2001). Faculty Publications: Department of Entomology. 792. https://digitalcommons.unl.edu/entomologyfacpub/792

This Article is brought to you for free and open access by the Entomology, Department of at DigitalCommons@University of Nebraska - Lincoln. It has been accepted for inclusion in Faculty Publications: Department of Entomology by an authorized administrator of DigitalCommons@University of Nebraska - Lincoln. 


\title{
Arthropod Populations and Rice Yields in Direct-Seeded and Transplanted Lowland Rice in West Africa
}

\author{
I. O. Oyediran and E. A. Heinrichs
}

Department of Entomology, University of Nebraska-Lincoln, Lincoln, Nebraska, USA

Corresponding author - E. A. Heinrichs, Department of Entomology, University of Nebraska, 202 Plant IndustryEast Campus, Lincoln, NE 68583-0816, USA, fax +402 472-4687, email eheinric@unlnotes.unl.edu

\begin{abstract}
Two methods for planting rice in irrigated lowland were evaluated during the wet seasons of 1994 and 1995 to determine their effect on rice arthropod numbers, insect-caused rice plant damage, and rice grain yield. The six treatments tested were: hand transplanting of seedlings at spacings of $14 \mathrm{~cm}$ $\times 14 \mathrm{~cm}, 20 \mathrm{~cm} \times 20 \mathrm{~cm}$, and $30 \mathrm{~cm} \times 30 \mathrm{~cm}$; and direct-seeding of rice at $60 \mathrm{~kg}$ seeds ha ${ }^{-1}, 90 \mathrm{~kg}$ seeds $\mathrm{ha}^{-1}$, and $120 \mathrm{~kg}$ seeds ha-1. The most abundant arthropods in the study were the diopsid flies, Diopsis longicornis Maquart and D. apicalis Dalman; the green leafhoppers Nephotettix spp.; the white leafhoppers Cofana unimaculata (Signoret) and C. spectra (Distant); spiders; dragonflies and damselflies; and stem borers. There was no overall difference between transplanting and direct-seeding, or between plant densities, in regard to sweep net counts of Cofana spp. and spiders. Diopsis longicornis and $D$. apicalis adult numbers were highest in the $20 \mathrm{~cm} \times 20 \mathrm{~cm}$ transplanted plots in 1994, but no significant differences occurred in 1995. Nephotettix spp. adult numbers were highest in the $120 \mathrm{~kg}$ seeds ha ${ }^{-1}$ direct-seeded plots in 1995, but no significant differences occurred in 1994 . The percentage of tillers infested with stem borers was highest in the three transplanted and the $120 \mathrm{~kg}$ seed ha-1 direct-seeded treatments in 1994 and the three transplanted treatments in 1995. In 1995, the percentage of whiteheads (empty panicles) caused by stem-borer feeding was highest in the direct-seeded treatments, increasing from the low rate of $60 \mathrm{~kg}$ seeds ha-1 to the highest rate of $120 \mathrm{~kg}$ seeds ha-1. Grain yields were generally similar in the transplanted and direct-seeded plots. Implications of planting methods and plant density as management practices in rice IPM and labor requirements for rice production are discussed.
\end{abstract}


Keywords: Côte d'Ivoire, West Africa, Oryza sativa L., rice insect pests, planting method, leafhoppers, spiders, stem borers, dragonflies, damselflies

\section{Introduction}

In West Africa, the most common method of planting of rice in irrigated lowland fields is by the transplanting of seedlings that have been grown in a nursery bed. However, in recent years there has been considerable interest in seeding (broadcast or drilled in rows) directly in the field. According to Poussin (1997), both planting methods present certain advantages and disadvantages.

A major consideration, regarding the choice of transplanting or direct-seeding of rice, is weeding. In West Africa, weeds are a major constraint upon rice production (Dingkuhn, 1993; Johnson, 1997). Direct-seeded rice requires more accurate field leveling and more precise water management (Béliéres et al., 1994). Early flooding just after broadcasting of seeds, and poor drainage, are major constraints upon adoption of direct-seeded rice in Thailand (Konchan and Kono, 1996). Lack of standing water in direct-seeded rice results in weed growth. Hand weeding is difficult because of the necessity of avoiding stepping on the closely spaced seedlings and because certain weed species are similar in appearance to rice seedlings. As a result, herbicide application may be necessary. Transplanting rice seedlings in the field, on the other hand, allows the farmer to maintain standing water in the field, which mitigates weed growth and provides a comparative height advantage for the newly established rice seedlings over those of the weeds. Moreover, transplanting in rows facilitates manual weeding. At plant spacings of $20 \mathrm{~cm} \times 20 \mathrm{~cm}$ or wider, it is easy for the farmer to enter the field and hand-remove weeds. Direct-seeding is thus most suitable to areas where there is a labor shortage, mechanization is available for land preparation, and where irrigation water can be effectively managed. In the West African Senegal River Valley, the use of direct-seeding has been linked to large irrigation schemes while transplanting is most common in the village irrigation schemes (Poussin, 1997).

De Datta (1986) reported that rice production in Asia requires 32 man days ha ${ }^{-1}$ preharvest for a direct-seeded crop compared with 63 days for a transplanted crop. Directseeded rice culture on irrigated rice farms in the Philippines releases labor, mostly that of women, for other agricultural activities (Tisch and Paris, 1994).

Primarily because of the labor-saving advantage of direct-seeding rice, there has been worldwide interest in this planting method. Konchan and Kono (1996) reported that there was a drastic shift from transplanting of rice to direct-seeding in the northeastern part of Thailand. The farmers in Thailand consider minimizing labor input in rice cultivation of greater importance than maximizing grain yields. With the current shortage and increasing cost for agricultural labor in West Africa, direct-seeding rice presents a distinct advantage.

In the development of rice IPM strategies for West Africa, there is a need to consider the impact of changing planting methods on rice insects and subsequent grain yields. Several studies have been conducted to determine the importance of spatial properties of rice on the population dynamics of various arthropods. In studies conducted at the same location 
as the current study, Oyediran et al. (1999) found that when rice seedlings were transplanted, populations of diopsid flies Diopsis longicornis and D. apicalis, percentage of tillers with deadhearts or whiteheads caused by stem-borer feeding, and grain yields were generally higher at a close spacing of $10 \mathrm{~cm} \times 10 \mathrm{~cm}\left(100\right.$ hills m $\left.\mathrm{m}^{-2}\right)$ compared with a wider spacing of $30 \mathrm{~cm} \times 30 \mathrm{~cm}\left(10\right.$ hills $\left.\mathrm{m}^{-2}\right)$. In Nigeria, infestation by the rice gall midge Orseolia oryzivora Harris and Gagne was increased with close plant spacing of transplanted crops (Ukwungwu, 1987a). In the USA, Thompson and Quisenberry (1995) reported that the rice water weevil, Lissorhoptrus oryzophilus Kuschel, laid more eggs at lower plant densities. In India (Singh et al., 1990; Sathiyanandam et al., 1991), plant spacing did not affect the incidence and extent of damage by the yellow stem borer, Scirpophaga incertulas (Walker) on rice. In studies conducted in Guinea, Chiasson and Hill (1993) reported that damage by Diopsis spp. was three times more severe in transplanted rice than in direct-seeded rice in the dry season, but no significant differences in damage between planting methods occurred during the wet season. Based on these studies, it is apparent that the effect of planting methods and planting density depends on the insect species being studied and the season, the most common effect being some increase in insect populations and insect damage with a close plant spacing.

Published studies comparing the effect of transplanting and direct-seeding on rice insect populations in West Africa have been limited to that of Chiasson and Hill (1993) on Diopsis spp. populations. However, in the development of IPM strategies for lowland rice in West Africa, more information is needed to determine the effect of each of these rice-planting methods on insect pest and natural enemy numbers. This study was conducted to generate information on the effect of transplanting and direct-seeding, at different plant densities, on the abundance of beneficial and pest arthropods, plant damage caused by insects, and rice grain yield.

\section{Methods}

This study was conducted in a lowland area on the West Africa Rice Development Association (WARDA) M'bé Research Station near Bouaké, Côte d'Ivoire during the wet seasons (August to November) in 1994 and 1995. This station is located in the transition zone between the humid forest and derived savanna.

The lowland plots were prepared by using the wetland tillage method described by De Datta (1981). Plot size was $10 \mathrm{~m} \times 12 \mathrm{~m}$. Two planting methods were tested:

1. Seeds of rice cultivar Bouaké 189 were sown in nurseries, and at 21 days after sowing, seedlings were transplanted in puddled soil at three spacings: $14 \mathrm{~cm} \times 14 \mathrm{~cm}$, $20 \mathrm{~cm} \times 20 \mathrm{~cm}$, and $30 \mathrm{~cm} \times 30 \mathrm{~cm}$. These plant spacings correspond to plant populations of 50, 25, and 10 hills $\mathrm{m}^{-2}$, respectively.

2. On the same date that transplanting was done, Bouaké 189 seeds were sown directly into plots of puddled soil by hand-broadcasting at three seed rates: $60 \mathrm{~kg} \mathrm{ha}^{-1}$, $90 \mathrm{~kg} \mathrm{ha}^{-1}$, and $120 \mathrm{~kg} \mathrm{ha}^{-1}$. Bouaké 189 is a commonly grown commercial cultivar in Côte d'Ivoire (Becker and Diallo, 1992) and neighboring West African countries, having a growth duration from planting to harvest of 100-105 days. 
Fertilizer (NPK 10-18-10) was incorporated into the soil at the rate of $150 \mathrm{~kg} \mathrm{ha}^{-1}$ just prior to time of planting. Urea (45\%) at $75 \mathrm{~kg} \mathrm{ha}^{-1}$ was broadcast at 30 and 60 days after transplanting (DT) or after seeding (DS). The experiment was planted in a randomized complete block design with four replications.

Arthropod populations were determined by taking 50 sweeps per plot (120 $\mathrm{m}^{2}$ area), with a sweep net at fortnightly intervals from the second to the 12th week after planting. To determine the percentage of tillers damaged by stem-borer larvae, deadhearts were counted fortnightly through the vegetative stage by examining 50 randomly selected hills per plot. Percentage of stem borer-infested tillers was determined by dissecting the tillers on 10 randomly selected hills per plot at 30,50, and 70 DT or DS. Whiteheads (chaffy or empty whitish colored panicles) caused by stem-borer feeding during the reproductive phase or rice production were counted on all productive tillers of 50 randomly selected hills per plot just prior to harvest. To determine yield, a $36 \mathrm{~m}^{2}$ area in the center of each plot was harvested, weighed, and the grain corrected for $14 \%$ moisture. Data were subjected to ANOVA and means separated by the LSD test $(P<0.05)$.

\section{Results}

The most abundant insects in sweep net catches over the 2-year period were the stemboring stalk-eyed flies, Diopsis longicornis Maquart and D. apicalis Dalman. Populations of both species were highest in 1995. Significant differences between treatments occurred only in 1994 (tables 1 and 2). In 1994, populations of D. longicornis were highest in the high plant density plots transplanted at $14 \mathrm{~cm} \times 14 \mathrm{~cm}$ (TP1) and $20 \mathrm{~cm} \times 20 \mathrm{~cm}$ (TP2), and lowest in the low plant density plots transplanted at $30 \mathrm{~cm} \times 30 \mathrm{~cm}$ (TP3) (figure 1, A). There was no significant difference between the three direct-seeding rates.

Table 1. ANOVA indicating source of variation, degrees of freedom, mean squares, and probability with $\mathrm{F}$ test $(P>F)$ for D. longicornis, $1994^{*}$

\begin{tabular}{lccc}
\hline Source of variation & $\mathrm{df}$ & MS & $P>F$ \\
\hline Replication & 3 & 749.6 & 0.014 \\
Treatments & 5 & 461.4 & 0.043 \\
Error & 15 & 151.4 & \\
\hline MS, mean squares (from type III sum of squares) & & \\
${ }^{*}$ 1995 data NS & & \\
& & & \\
\hline
\end{tabular}

Table 2. ANOVA indicating source of variation, degrees of freedom, mean squares, and probability with $\mathrm{F}$ test $(P>F)$ for D. apicalis, $1994^{*}$

\begin{tabular}{lrcl}
\hline Source of variation & $\mathrm{df}$ & MS & $P>F$ \\
\hline Replication & 3 & 53.5 & 0.487 \\
Treatments & 5 & 157.1 & 0.056 \\
Error & 15 & 62.8 & \\
\hline
\end{tabular}

MS, mean squares (from type III sum of squares)

*1995 data NS 


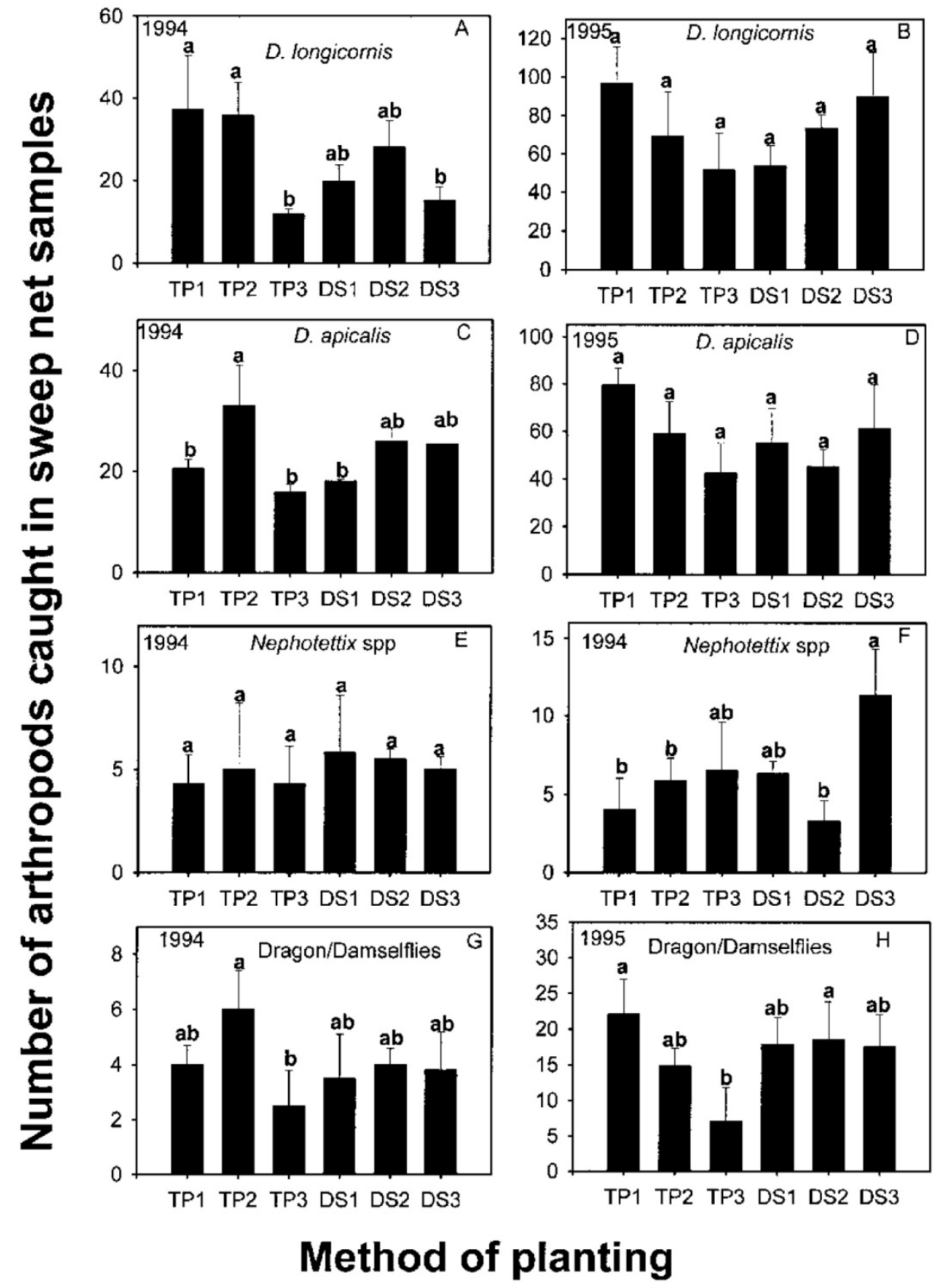

Figure 1. Number of insects per 50 sweeps with a sweep net in an irrigated lowland rice cultivar Bouaké 189, as affected by method of planting (transplanting and direct-seeded) over a 2-year period 1994-1995 (A-H). Transplanted at a spacing $14 \mathrm{~cm} \times 14 \mathrm{~cm}$ within and between rows (TP1), $20 \mathrm{~cm} \times 20 \mathrm{~cm}(\mathrm{TP} 2)$, and $30 \mathrm{~cm} \times 30 \mathrm{~cm}$ (TP3). Direct-seeded rice at $60 \mathrm{~kg}$ of seed ha-1 (DS1), $90 \mathrm{~kg} \mathrm{ha}^{-1}$ (DS2), and $120 \mathrm{~kg} \mathrm{ha}^{-1}$ (DS3). Standard error bars ( $P$ $=0.05$ ) compare statistical significance between the different planting methods. WARDA M’bé Research Station, Bouaké, Côte d'Ivoire. 
Diopsis apicalis numbers in 1994 (figure 1, C) were highest in the $20 \mathrm{~cm} \times 20 \mathrm{~cm}$ transplanting treatment (TP2). Similar to D. longicornis (figure 1, A), there were no significant differences in $D$. apicalis numbers in the direct-seeding treatments (figure $1, C$ ).

Nephotettix spp. numbers were low in both 1994 and 1995 (figure 1, E, F). Significant differences were observed only in 1995 (figure 1, F) (table 3). In 1995, the highest Nephotettix spp. numbers occurred in the highest direct-seeded rate of $120 \mathrm{~kg} \mathrm{ha}^{-1}$ (DS3) (figure 1, F).

Table 3. ANOVA indicating source of variation, degrees of freedom, mean squares, and probability with F test $(P>F)$ for Nephotettix spp., 1995*

\begin{tabular}{lccc}
\hline Source of variation & $\mathrm{df}$ & MS & $P>F$ \\
\hline Replication & 3 & 46.4 & 0.038 \\
Treatments & 5 & 31.5 & 0.054 \\
Error & 15 & 12.8 & \\
\hline MS, mean squares (from type III sum of squares) & & \\
${ }^{*}$ 1994 data NS & &
\end{tabular}

The numbers of the two Cofana species were not affected by the different planting methods in either 1994 or 1995.

Spiders were considered as a group and were not taxonomically classified to the generic level. However the major canopy-dwelling spider species in lowland rice on the site of this study are: Pardosa injucunda (Lawrence) (Lycosidae); Tetragnatha jaculator Tullgren and T. javana (Thorell) (Tetragnathidae); Araneus sp., Argiope sp., and Neoscona sp. (Araneidae); Dolomedes sp. (Pisauridae); and Runcinia sp. (Thomisidae) (Oyediran and Heinrichs, 1999). The spider numbers, which ranged from 5 to 11 per 50 sweeps in 1994 and 5 to 7 in 1995, were not affected by planting method or plant density.

Planting methods significantly affected the populations of the predators, the dragonflies (Odonata: Libellulidae including Palpopleura sp.), and the damselflies (Odonata: Libellulidae including Lestes sp. and Coenagrionidae including Agriocnemis sp.) in both years (tables 4 and 5). In 1994, the highest population was found in rice transplanted at $20 \mathrm{~cm} \times 20 \mathrm{~cm}$ (TP2) and the lowest was in $30 \mathrm{~cm} \times 30 \mathrm{~cm}$ (TP3) spaced treatments (figure 1, G). In 1995, the highest population occurred in the plots transplanted at $14 \mathrm{~cm} \times 14 \mathrm{~cm}$ (TP1) and the lowest in the $30 \mathrm{~cm} \times 30 \mathrm{~cm}(\mathrm{TP} 3)$ treatment (figure $1, \mathrm{H}$ ).

Table 4. ANOVA indicating source of variation, degrees of freedom, mean squares, and probability with $\mathrm{F}$ test $(P>F)$ for dragon/damselflies, 1994

\begin{tabular}{lrcc}
\hline Source of variation & $\mathrm{df}$ & MS & $P>F$ \\
\hline Replication & 3 & 10.7 & 0.067 \\
Treatments & 5 & 5.8 & 0.058 \\
Error & 15 & 3.6 & \\
\hline
\end{tabular}

MS, mean squares (from type III sum of squares) 
Table 5. ANOVA indicating source of variation, degrees of freedom, mean squares, and probability with $\mathrm{F}$ test $(P>F)$ for dragon/damselflies, 1995

\begin{tabular}{lrcc}
\hline Source of variation & $\mathrm{df}$ & MS & $P>F$ \\
\hline Replication & 3 & 190.5 & 0.044 \\
Treatments & 5 & 103.8 & 0.054 \\
Error & 15 & 55.3 & \\
\hline
\end{tabular}

MS, mean squares (from type III sum of squares)

Percentage tillers infested with stem-borer larvae was significantly affected by planting methods in 1994 and 1995 (figure 2) (tables 6 and 7). Stem-borer larvae were not separated to the species level, but the major species infesting rice in the locale of this study are the dipterous larvae of the stalk-eyed flies, Diopsis longicornis and D. apicalis, and the lepidopterous larvae of the genera Maliarpha, Chilo, and Scirpophaga (Oyediran and Heinrichs, 1999). In 1994 (figure 2, A), tiller infestation was highest in the three transplanting treatments and the high rate of direct-seeding at $120 \mathrm{~kg}$ seeds ha- ${ }^{-1}$ (DS3). The lowest level was in the low seeding rate of $60 \mathrm{~kg} \mathrm{ha}^{-1}$ (DS1). Tiller infestation in 1995, was again high in the three transplanting treatments and lowest in the DS1 treatment (figure 2, B).

Table 6. ANOVA indicating source of variation, degrees of freedom, mean squares, and probability with $\mathrm{F}$ test $(P>F)$ for percentage tillers infested, 1994

\begin{tabular}{lrcc}
\hline Source of variation & df & MS & $P>F$ \\
\hline Replication & 3 & 15.2 & 0.064 \\
Treatments & 5 & 4.4 & 0.056 \\
Error & 15 & 2.4 & \\
\hline
\end{tabular}

MS, mean squares (from type III sum of squares)

Table 7. ANOVA indicating source of variation, degrees of freedom, mean squares, and probability with $\mathrm{F}$ test $(P>F)$ for percentage tillers infested, 1995

\begin{tabular}{lrcc}
\hline Source of variation & $\mathrm{df}$ & MS & $P>F$ \\
\hline Replication & 3 & 17.8 & 0.194 \\
Treatments & 5 & 22.3 & 0.057 \\
Error & 15 & 10.1 & \\
\hline
\end{tabular}

MS, mean squares (from type III sum of squares) 


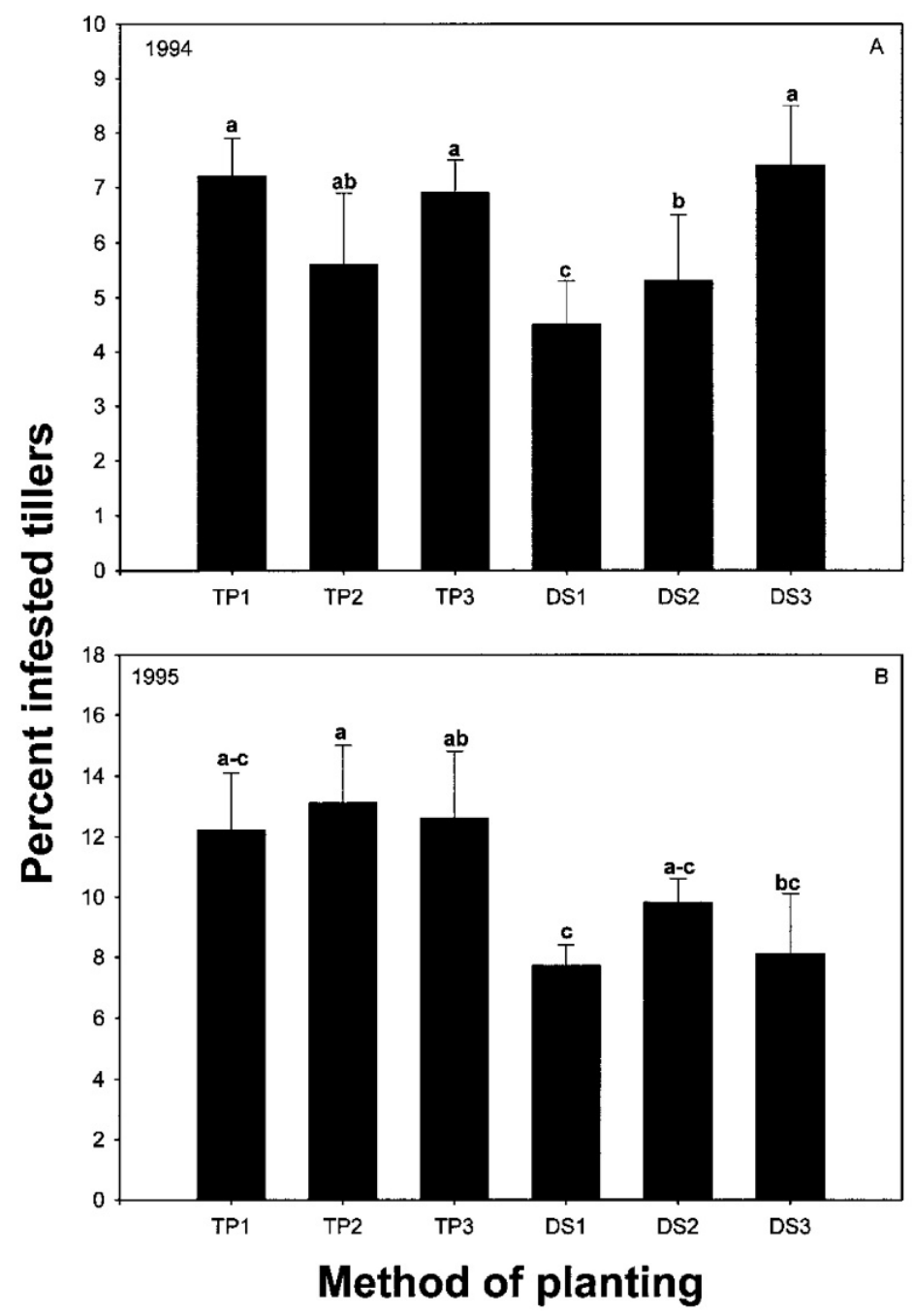

Figure 2. Stem-borer damage (\% tillers with stem-borer larvae) in an irrigated lowland rice cultivar Bouaké 189, as affected by method of planting (transplanting and directseeded) over a 2-year period 1994-1995 (A-B). Transplanted at a spacing $14 \mathrm{~cm} \times 14 \mathrm{~cm}$ within and between rows (TP1), $20 \mathrm{~cm} \times 20 \mathrm{~cm}$ (TP2), and $30 \mathrm{~cm} \times 30 \mathrm{~cm}$ (TP3). Directseeded rice at $60 \mathrm{~kg}$ of seed ha-1 (DS1), $90 \mathrm{~kg} \mathrm{ha}^{-1}$ (DS2), and $120 \mathrm{~kg} \mathrm{ha}^{-1}$ (DS3). Standard error bars $(P=0.05)$ compare statistical significance between the different planting methods. WARDA M'bé Research Station, Bouaké, Côte d'Ivoire.

Percentage deadhearts caused by stem-borer feeding was affected by planting method in 1994 (table 8). The lowest percentage deadhearts was in the lowest seeding rate of $60 \mathrm{~kg} \mathrm{ha}^{-1}$ (DS1) (figure 3). Percentage whiteheads did not vary significantly between treatments in 1994. In 1995 significant differences between treatments occurred (table 9) with the directseeded plots having the highest whitehead percentage (figure 4). Percentage whiteheads in the $120 \mathrm{~kg}$ seed ha-1 treatment (DS3) was about twice that of the TP1 and TP2 treatments. 
Oyediran And Heinrichs, international Journal of PESt MANAGEMENT 47 (2001)

Table 8. ANOVA indicating source of variation, degrees of freedom, mean squares, and probability with $\mathrm{F}$ test $(P>F)$ for deadhearts, $1994^{*}$

\begin{tabular}{lrcc}
\hline Source of variation & $\mathrm{df}$ & MS & $P>F$ \\
\hline Replication & 3 & 3.6 & 0.003 \\
Treatments & 5 & 1.4 & 0.056 \\
Error & 15 & 0.5 & \\
\hline
\end{tabular}

MS, mean squares (from type III sum of squares)

*1995 data NS

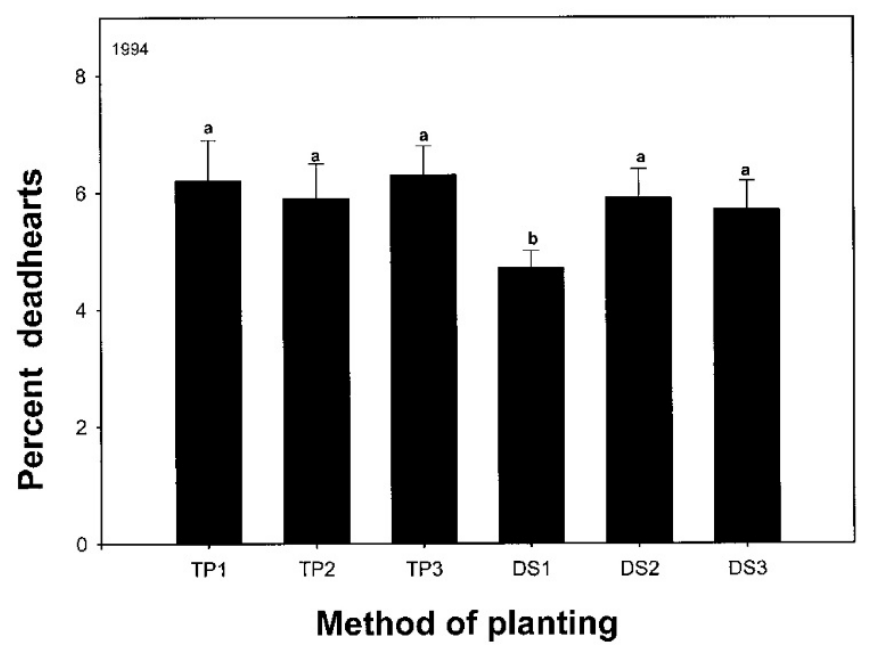

Figure 3. Stem-borer damage (\% dead tillers, "deadhearts") in an irrigated lowland rice cultivar Bouaké 189, as affected by method of planting (transplanting and direct-seeded) in 1994. Transplanted at a spacing of $14 \mathrm{~cm} \times 14 \mathrm{~cm}$ within and between rows (TP1), 20 $\mathrm{cm} \times 20 \mathrm{~cm}(\mathrm{TP2})$, and $30 \mathrm{~cm} \times 30 \mathrm{~cm}$ (TP3). Direct-seeded rice at $60 \mathrm{~kg} \mathrm{ha}^{-1}(\mathrm{DS} 1), 90 \mathrm{~kg}$ $\mathrm{ha}^{-1}(\mathrm{DS} 2)$, and $120 \mathrm{~kg} \mathrm{ha}^{-1}(\mathrm{DS} 3)$. Standard error bars $(P=0.05)$ compare statistical significance between the different planting methods.

Table 9. ANOVA indicating source of variation, degrees of freedom, mean squares, and probability with $\mathrm{F}$ test $(P>F)$ for whiteheads, $1995^{*}$

\begin{tabular}{lrcc}
\hline Source of variation & $\mathrm{df}$ & MS & $P>F$ \\
\hline Replication & 3 & 53.0 & 0.416 \\
Treatments & 5 & 141.3 & 0.052 \\
Error & 15 & 52.6 & \\
\hline
\end{tabular}

MS, mean squares (from type III sum of squares)

*1994 data NS 


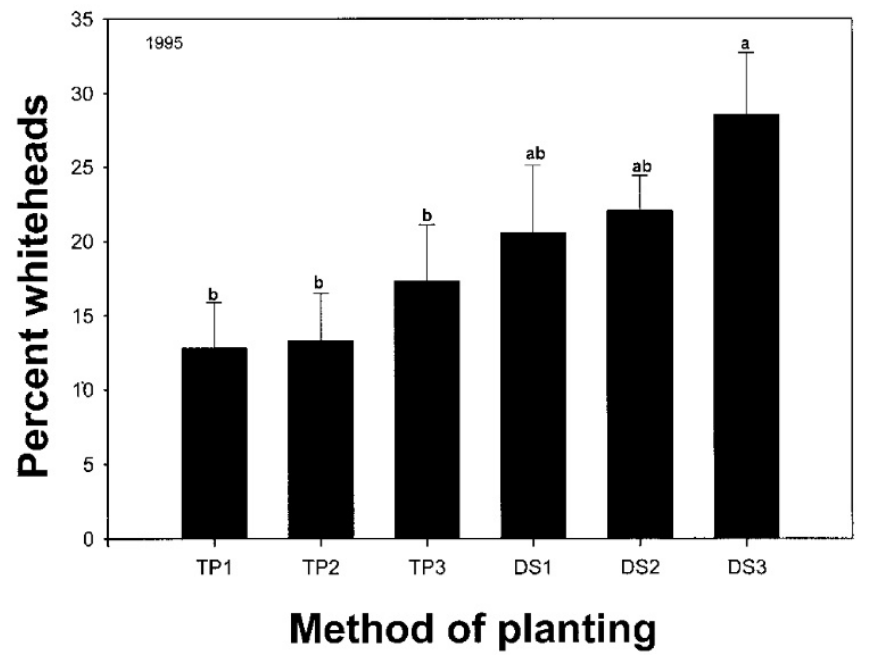

Figure 4. Stem-borer damage (\% damaged panicles, "whiteheads") in an irrigated lowland rice cultivar Bouaké 189, as affected by method of planting (transplanting and directseeded) over a 2-year period 1994-1995 (A-B). Transplanted at a spacing $14 \mathrm{~cm} \times 14 \mathrm{~cm}$ within and between rows (TP1), $20 \mathrm{~cm} \times 20 \mathrm{~cm}$ (TP2), and $30 \mathrm{~cm} \times 30 \mathrm{~cm}$ (TP3). Directseeded rice at $60 \mathrm{~kg}$ of seed ha-1 (DS1), $90 \mathrm{~kg} \mathrm{ha}^{-1}$ (DS2), and $120 \mathrm{~kg} \mathrm{ha}^{-1}$ (DS3). Standard error bars $(P=0.05)$ compare statistical significance between the different planting methods. WARDA M'bé Research Station, Bouaké, Côte d'Ivoire.

Grain yields were about $25-40 \%$ higher in 1994 than in 1995 . Grain yields were significantly affected by planting methods in 1994 (table 10) but not in $1995(P>F=0.280)$. Highest yields $\left(5,200 \mathrm{~kg} \mathrm{ha}^{-1}\right)$ in 1994 were recorded in the $30 \mathrm{~cm} \times 30 \mathrm{~cm}$ transplanted plots (TP3) and the lowest $\left(3,450 \mathrm{~kg} \mathrm{ha}^{-1}\right)$ were in direct-seeded rice at $90 \mathrm{~kg}$ seed ha-1 (DS2) (figure 5).

Table 10. ANOVA indicating source of variation, degrees of freedom, mean squares, and probability with $\mathrm{F}$ test $(P>F)$ for rice grain yields in $\mathrm{kg} \mathrm{ha}^{-1}, 1994^{*}$

\begin{tabular}{lrcc}
\hline Source of variation & df & MS & $P>F$ \\
\hline Replication & 3 & 489,484 & 0.519 \\
Treatments & 5 & $3,634,265$ & 0.004 \\
Error & 15 & 619,987 & \\
\hline
\end{tabular}

MS, mean squares (from type III sum of squares)

*1995 data NS 


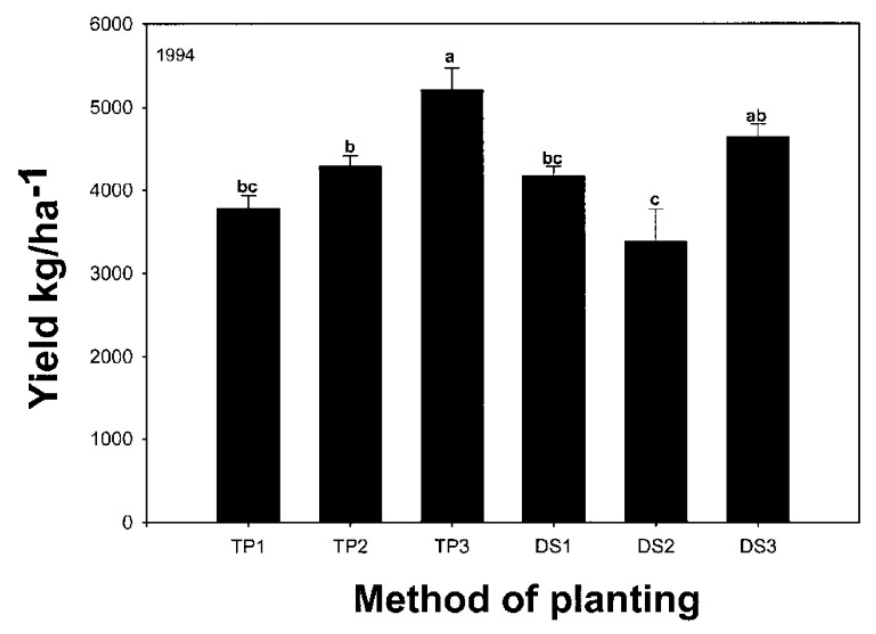

Figure 5. Grain yields $\mathrm{kg} \mathrm{ha}^{-1}$ of an irrigated lowland rice cultivar Bouaké 189, as affected by method of planting (transplanting and direct-seeded) in 1994. Transplanted at a spacing $14 \mathrm{~cm} \times 14 \mathrm{~cm}$ within and between rows (TP1), $20 \mathrm{~cm} \times 20 \mathrm{~cm}(\mathrm{TP} 2)$, and $30 \mathrm{~cm} \times 30 \mathrm{~cm}$ (TP3). Direct-seeded rice at $60 \mathrm{~kg}$ of seed ha-1 (DS1), $90 \mathrm{~kg} \mathrm{ha}^{-1}$ (DS2), and $120 \mathrm{~kg} \mathrm{ha}^{-1}$ (DS3). Standard error bars $(P=0.05)$ compare statistical significance between the different planting methods. WARDA M'bé Research Station, Bouaké, Côte d'Ivoire.

\section{Discussion and conclusions}

The effect of planting method (transplanting vs. direct-seeding) and plant density (spacing of transplanted seedlings and seed rate ha-1) on sweep net counts of insects, insect damage and grain yield was not distinct, and varied between 1994 and 1995. Diopsis populations tended to be highest in close plant spacings, whether transplanted or direct-seeded (figure 1, A-D). Results of another study conducted at this same location in 1996 indicated highest adult Diopsis numbers in closely transplanted hills (Oyediran et al., 1999). Alghali (1984) reported a three-fold increase in Diopsis eggs per hill with a decrease of plant density from a $15 \mathrm{~cm} \times 15 \mathrm{~cm}$ to $30 \mathrm{~cm} \times 30 \mathrm{~cm}$ spacing between hills, but the percentage deadhearts due to Diopsis feeding did not differ. Chiasson and Hill (1993) compared the effect on Diopsis damage of transplanting at $20 \mathrm{~cm} \times 20 \mathrm{~cm}$ between hills with direct-seeding (seed rate ha${ }^{1}$ not indicated). Their results indicated that, in both years of their study, Diopsis damage in transplanted rice was three times that in direct-seeded rice in the dry season, but in the wet season crop, damage was more in the direct-seeded rice one year, and there was no significant difference the next year. Percentage infested tillers (partially due to Diopsis spp.) in our study, which was conducted during the wet season, was highest in the transplanted treatments in 1995, but differences in 1994 varied within each planting method (transplanting and direct-seeding (figure 2). It is apparent that Diopsis numbers and Diopsis-caused plant damage are affected by some factor(s) differing from one year to another, which tend to confound the effects of the planting methods.

Planting method and plant spacing had little effect on percentage deadhearts caused by stem-borer feeding. In studies conducted in India, Singh et al. (1990) and Sathiyanandam 
et al. (1991) reported that rice plant spacings had no effect on incidence of the yellow stem borer, Scirpophaga incertulas (Walker). Studies in Malaysia indicated no difference in incidence of the stem borer Chilo suppressalis (Walker) between transplanted and direct-seeded rice fields (Lee and Ma, 1997).

Planting method and plant density had a statistically significant effect on rice grain yield only in 1994. In 1994, rice transplanted at $30 \mathrm{~cm} \times 30 \mathrm{~cm}$ had the highest grain yield (figure 5). Ukwungwu (1987b) reported an $800 \mathrm{~kg} \mathrm{ha}^{-1}$ yield increase from a $15 \mathrm{~cm} \times 15 \mathrm{~cm} \mathrm{spacing}$ of transplanted hills to a spacing of $30 \mathrm{~cm} \times 30 \mathrm{~cm}$ between hills. This is similar to our results in 1994 (figure 5, TP1 $=14 \mathrm{~cm} \times 14 \mathrm{~cm}$ vs. TP3 $=30 \mathrm{~cm} \times 30 \mathrm{~cm}$ ). However, in the 1995 test no significant differences among treatments occurred. Oyediran et al. (1999) conducted a spacing study with transplanted seedlings at this same site. They reported that widely spaced plants are able to compensate, to a certain extent, by producing more tillers per plant than closely spaced plants, thus resulting in similar yields for close and widely spaced plants. Thus, compensation may have been greater in 1995 than in 1994.

In the development of rice IPM strategies for lowland rice in West Africa, insect pest problems should not be a major concern in the decision as whether to transplant or directseed rice. Cultural practices such as irrigation and weeding, and their labor requirements, should be of greater concern to farmers.

\section{References}

Alghali, A. M., 1984. Effect of plant spacing on the infestation levels of rice by the stalk-eyed borer, Diopsis thoracica, West (Diptera: Diopsidae) Tropical Agriculture (Trinidad), 61, 74-75.

Becker, L., and Diallo, R., 1992. Caracterisation et Classification des Ecosystemes Rizicoles de la Côte d'Ivoire (Bouaké, Côte d'Ivoire: ADRAO), 255 pp.

Béliéres, J. F., Camara, S., and Touri, A., 1994. Les Exploitations Agricoles du Delta et leurs Résultats Technico-Éconmiques Pour la Production Rizicole en 1993 (St Louis, Sénégal: Société Nationale d'Aménagement et d'Exploitation des teres du Delta du fleuve Sénégal et des vallées du fleuve Sénégal et de la Falémé (SAED)), 70 pp. + annexes.

Chiasson, H., and Hill, S. B., 1993. Population density, development and behaviour of Diopsis longicornis and D. apicalis (Diptera: Diopsidae) on rice in the Republic of Guinée. Bulletin of Entomological Research, 83, 5-14.

De Datta, S. K., 1981. Principles and Practices of Rice Production (NewYork, USA: John Wiley and Sons), $618 \mathrm{pp}$.

De Datta, S. K., 1986. Technology development and the spread of direct-seeded flooded rice in southeast Asia. Experimental Agriculture, 22, 417-426.

Dingkuhn, M., 1993. Contraintes de rendement dans un périmétre irrigug du Sahel. Annual Report for 1992 (Bouaké, Côte d'Ivoire: West Africa Rice Development Association), pp. 40-41.

Johnson, D. E., 1997. Weeds of Rice in West Africa (Bouaké, Côte d'Ivoire: West Africa Rice Development Association), $312 \mathrm{pp}$.

Konchan, S., and Kono, Y., 1996. Spread of direct seeded lowland rice in northeast Thailand: farmers' adaptation on economic growth. Southeast Asian Studies, 33, 523-546.

Lee, S. C., and Ma, K. C., 1997. Occurrence of major insect pests in machine transplanted and direct seeded rice paddy field. Korean Journal of Applied Entomology, 36, 141-144. 
Oyediran, I. O., and Heinrichs, E. A., 1999. Seasonal abundance of rice-feeding insects and spiders in continuously cropped lowland rice in West Africa. Insect Science and Its Application, 19, 121-129.

Oyediran, I. O., Heinrichs, E. A., Traore, A. K. A., and Johnson, D. E., 1999. Plant spacing effect on insect pest abundance and yields of irrigated lowland rice in Côte d'Ivoire. Journal of Plant Protection in the Tropics, 12, 55-67.

Poussin, J. C., 1997. Direct seeding or transplanting? The example of the Senegal middle valley. In K. M. Miézan, M. C. S. Wopereis, M. Dingkuhn, J. Deckers and T.F. Randolph (eds.) Irrigated Rice in the Sahel: Prospects for Sustainable Development (Dakar, Senegal: West Africa Rice Development Association), pp. 191-200.

Sathiyanandam, V. K. R., Logiswaran, G., and Sundarababu, P. C., 1991. Influence of varieties, spacings and pest management on the incidence of three major pests of rice. Madras Agricultural Journal, 78, 10-14.

Singh, P., Sukhija, H. S., Gill, P. S., and Bangoo, B. S., 1990. Influence of agronomic manipulations on stem borer Scirpophaga incertulas Walker incidence in rice. Journal of Insect Science, 3, 148-151.

Thompson, R. A., and Quisenberry, S. S., 1995. Rice plant density effect on rice water weevil (Coleoptera: Curculionidae) infestation. Environmental Entomology, 24, 19-23.

Tisch, S. J., and Paris, T. R., 1994. Labor substitution in Philippine rice farming systems: an analysis of gender work roles. Rural Sociology, 59, 497-514.

Ukwungwu, M. N., 1987a. Effects of spacing and nitrogen fertilizer on infestation by the rice gall midge Orseolia oryzivora Harris and Gagné (Diptera: Cecidomyidae) in Nigeria. Tropical Pest Management, 33, 164-165.

Ukwungwu, M. N., 1987b. Some effects of plant densities and carbofuran on the damage by Diopsis thoracica West. and Maliarpha separatella Rag. and yield of rice in Nigeria. Tropical Pest Management, 33, 280-282. 